\title{
Achievement of student graduates: The role of e-readiness, e-learning and e-book
}

\author{
Agus Dudunga $^{a}$, Uswatun Hasanaha, Ibnu Salman ${ }^{\mathrm{b}}$, Sugeng Priyanto ${ }^{\mathrm{a}}$ and Tri Wahyudi \\ Ramdhan $^{c}$
}

\author{
${ }^{a}$ Universitas Negeri Jakarta, Indonesia \\ ${ }^{b}$ National Research and Innovation Agency Republic of Indonesia \\ ${ }^{c}$ STAI Darul Hikmah Bangkalan, Indonesia \\ C H R O N I C L E
}

Article history:

Received: October 20, 2021

Received in revised format: No-

vember 18, 2021

Accepted: December 27, 2021

Available online: December 27 2021

Keywords:

E-readiness

E-learning

E-book

Graduate students

\begin{abstract}
A B S T R A C T
This study aims to determine the effect of e-readiness, e-learning, e-book on the achievement of graduate students; and the influence of e-readiness, e-learning, and e-books on the achievement of graduate students. The research population is graduate students with a sample of 210 doctoral students in Jakarta. The sample selection method is simple random sampling. The research method is a survey method with an associative approach. The data analysis technique is structural equation modeling (SEM) using SmartPLS 3.3.3 software and the data was obtained through the distribution of online questionnaires. The results show that there was an effect of e-readiness on graduate achievement; there was an effect of e-learning on graduate achievement; and finally, there was an effect of e-books on graduate achievement. This research can indicate that the curriculum developed by the students is in accordance with the learning outcomes, especially in the implementation of the learning process.
\end{abstract}

\section{Introduction}

Currently the world is being hit by Covid-19 cases, even countries Those affected by this lockdown have implemented a lockdown to minimize the spread of Covid-19. One of the affected countries is Indonesia. The government is taking steps decisively to break the chain of the spread of Covid-19. The existence of Covid-19 has an impact unhealthy in various sectors, one of which is in the field of education. In this digital era, the development of information and communication technology and its application is growing very rapidly, and almost all areas of life apply information and communication technology, including education. According to Alshammari et al. (2019), Bubou and Job (2021) This technology is intended to make it easier for humans to communicate with each other quickly, easily and affordably and has the potential to encourage community development. This technology helps people in organizing themselves effectively and efficiently for their own welfare. Information and communication technology in the field of education, among others, plays a role in facilitating academic administration, registration, and teaching and learning processes. Communication as an educational medium can be done by using the role of information and communication technology such as e-learning. According to Bose et al. (2017) and Fernando (2018), the next development is the birth of information and communication technology with the internet network. Many types of media categories on the internet based on websites are used for personal and community publications. Connectivism can be understood as a paradigm that focuses on the concept of networking in social life and contemporary cultural phenomena. The paradigmatic conception of connectivism in the current era of digital technology is indeed formed from information

* Corresponding author.

E-mail address: agusdudung@unj.ac.id (A. Dudung)

(C) 2022 by the authors; licensee Growing Science, Canada. doi: $10.5267 /$ j.ijdns.2021.12.017 
networks (the internet). This needs to be developed as well as part of the learning process which is expected to bridge the development of information technology to increase capacity and effectiveness in learning.

According to Fernando (2018), the use of information and communication technology in the lecture process that can be accessed by students from various sources can encourage students to be more effective in the lecture process. This context demands self-ability towards technological literacy known as e-readiness. This ability can motivate students to develop elearning patterns which are the impact of e-readiness abilities. E-books are a source of learning that can become a more effective learning discourse as learning education resources which are currently an unavoidable trend. Self-efficacy supported by this learning facility is expected to improve student achievement in completing their studies. According to Haryudin and Imanullah (2021), Fernando (2018) and Iffat et al. (2020), curriculum and learning innovation is intended as an idea or certain action in the field of curriculum and learning that is considered new to solve educational problems. Curriculum innovation problems are related to the principle of relevance between learning materials and student needs, between the quality of learning in lectures and the use of graduates in the field of work. The suitability of the curriculum developed by the study program should not override the knowledge that is currently developing and at least describe the future which must become the competence of graduates who will work in the working community and industrial society.

According to Iffat et al. (2020) and Keshavarz and Noorafrooz (2020), the use of this cutting-edge digital technology, of course, must be followed by the preparation of facilities and human resources for its application, especially in educational institutions. The Mechanical Technology D3 Study Program has tried to implement lecture models and systems by utilizing information technology, but the integration of information technology needs to be well designed from planning (curriculum) to student achievement (graduates). The impact of the application of information technology with the implementation of this information technology-based curriculum needs further research. This study aims to determine; the effect of e-readiness, elearning, e-book on the achievement of graduate students; and the influence of e-readiness, e-learning, and e-books on the achievement of graduates of the Doctoral program.

\section{Literature Review}

\subsection{Contextual Learning}

Contextual learning is a learning approach that emphasizes the full involvement of students to be able to find the material being studied and relate it to real-life situations to encourage students to apply it in their lives. According to Kolo and Zuva(2018), Kuruliszwili (2015), Kiilu et al. (2018) and Nisperos (2014), there are five important characteristics in using the contextual learning process, regard to aspects of life and the environment, the learning approach with involvement, activity, experience, independence, as well as the context of life and environment of students in contextual learning is seen as individuals' characteristics. In this regard, Kiilu et al. (2018) and Nisperos (2014) stated that in contextual learning, there are at least three main principles that are often used, namely: interdependence of differentiation and organization. Analysis of contextual learning requires comprehensive teaching materials. According to Kiilu et al. (2018) and Nisperos (2014), teaching materials are a set of materials used by students to carry out learning activities. Teaching materials can be packaged in such a way to attract students so that they are easily distributed effectively and efficiently in achieving learning goals. Teaching materials can be categorized into two groups, namely teaching materials and non-printed teaching materials. The developed teaching materials can be used as the main source of learning and supporting teaching materials for enrichment. Teaching materials in the learning process are used for independent study without direct guidance from lecturers, there is a tendency for these teaching materials to be suitable for learning purposes that are not limited by time and place. The steps for developing teaching materials begin with analyzing the curriculum, competency targets and learning outcomes. By paying attention to the systematic writing of teaching materials, the completeness of teaching materials obtained from the curriculum, design of learning implementation and evaluation, it can be designed teaching materials based on information technology.

\section{E-readiness}

E-learning readiness or e-readiness is a new concept. Readiness means being physically and mentally ready to do something. E-readiness also affects the success of educational programs that use information and communication technology in the academic process. The definition of e-readiness differs from one researcher to another. E-readiness is the degree to which people are prepared to participate in technologies that can help to build towards a better society. According to Kolo and Zuva(2018), Kuruliszwili (2015) and Kiilu et al. (2018), e-readiness is the mental or physical readiness of an organization for an e-learning experience or action (in Priyanto, 2008). Almost the same as the opinion by Kiilu et al. (2018) and Nisperos (2014) which states that e-readiness is the level where people are ready to get the benefits that can be obtained through information and communication technology. Meanwhile, according to Nisperos (2014) e-readiness is the ability to pursue opportunities to create value facilitated using the internet. Rosenberg (2000) states that e-readiness is an effective instrument to evaluate the effectiveness of e-learning. In this case, e-readiness is seen as a tool that guides the development of e-learning from the analysis stage to the evaluation stage. Knowledge is the first part and provides the basic information needed. The individual may have the knowledge to do something, but he chooses not to do it. Attitudes is the second part that deals with the feelings, beliefs and tendencies of a person to behave from innate and environmental factors that have a strong influence on behavior. Although individual knowledge and attitude has a good basis for Synchronous Distance Learning (SDL), it cannot be done 
without skills. When the knowledge, attitude, and skills are possessed, the formation of positive habits can support the success of one's e-learning.

According to Kolo and Zuva(2018), Kuruliszwili (2015), Kiilu et al. (2018) and Nisperos (2014), SDL is a process in which students, with or without assistance from others, identify learning needs, define learning objectives, develop and implement lesson plans, and evaluate learning that has been obtained. According to Gibbons (2002), SDL is an increase in knowledge, ability, achievement, or self-development that is chosen and carried out by an individual in any way and whenever desired. The SDL characteristics associated with successful e-learning in the literature is known as independence self-direction or autonomy in learning. According to Timothy et al. (2016), Zdraveski et al. (2021), Zubaedah et al. (2021) also has four components, namely knowledge, attitudes, skills, and habits. Self-Directed Learning Knowledge is an important requirement in readiness for SDL is self-knowledge: understanding of oneself as a student (learner). This includes knowledge of initiative, persistence, and self-awareness to perceive and process information. Readiness for SDL also includes self-study arrangements. Self-Directed Learning Attitudes are a major component of readiness for SDL. Attitudes are formed based on a strong desire to learn or change. Individuals who have a strong curiosity and love to learn new things focus on continuous self-development, view learning to solve problems and tend to be successful e-learning learners. Self-directed students believe that the main responsibility for learning lies with themselves.

\section{E-Learning}

In an e-learning setting that has been designed, creativity and independence are also very much needed in the learning process. According to Zdraveski et al. (2021) and Zubaedah et al. (2021), challenging e-learning requires the ability to think creatively and develop one's thinking and processes for identifying and solving problems as opposed to just following directions. Effective self-directed students use all available tools, being individuals who are willing to ask questions, clarify, or seek expert advice will always try. For Self-Directed Learning Skills, logically, basic academic skills are an important part of e-readiness, especially reading skills. According to Zdraveski et al. (2021) and Zubaedah et al. (2021), self-directed students are usually able to identify and analyze their learning needs. The abilities related to these learning needs are the ability to plan learning objectives, develop lesson plans, identify learning resources, implement learning, and evaluate learning. The ability to manage time and prepare documents or reports can support this process. For Self-Directed Learning Habits, one of the important habits in self-directed students is persistence - persistence to achieve goals despite problems, boredom, or other factors that are being hit. Habits such as systematic planning,

According to Kolo and Zuva(2018), Kuruliszwili (2015), Kiilu et al. (2018) and Nisperos (2014) arranging media and learning materials and completing tasks according to a planned schedule can increase the effectiveness of e-learning. Two other important habits include reflection and environmental scanning. Reflective individuals think about an action or event, the possible outcomes of that action or event, self-performance, how their actions will be interpreted by others, and analyze selflearning, learning processes, and learning outcomes. In other words, a reflective individual is an individual who sees everything from a macro and micro perspective in search of new insight or understanding. Environmental scanning is awareness of changes and possible impacts in an environment, including the need for new learning.

The development of the industrial revolution 4.0 has made it easier humans to carry out their activities, where most of the activities use technology. Industrial revolution 4.0 impact on the world of higher education, the use of technology greatly facilitates the process learning that is not limited by space and time, so that produce smart graduates and capable graduates compete with the demands of development.

E-learning or electronic learning is one of the examples of today's learning systems, e-learning brings the effect of the educational transformation process conventional into digital form, where the process learning is more flexible and interesting because in e-learning the presentation of learning materials combines several elements such as text, graphics, audio and video. But in implementation, it turns out that e-learning alone is not enough because there are still various obstacles, with e-learning there is an interaction in the learning process because the system more student-centered e-learning where the lecturer acts more as a facilitator and student play a more active role as an active participant in the learning process teach. Feedback is certainly needed so that learning outcomes are better effective and efficient. Therefore, it is also necessary to Blend Learning. Blended learning consists of the word blended (combination/mixed) and learning (learning), then blended learning is a combination of face-to-face learning face) and computer-based learning or learning online. The purpose of blended learning is in addition to improving learning outcomes, also useful for improving relationships communication, a sense of community among students. Learning with the material blended learning system learning can be conveyed directly with meeting in the classroom or online one of them with the use of MOODLE.

Learning media is a vehicle for distributing messages and learning information that is well designed to help students digest and understand the subject matter (Purwanto \& Juliana, 2021). There are several types of learning media, namely visual learning media, learning media The selection of a type of learning media is one of the most important parts in the learning process in the classroom. One of them is e-learning learning media, e-learning as an instruction process that involves the use of electronic equipment in delivering, assessing, creating, fostering, and facilitating all student-centered learning processes and carried out interactively wherever and whenever distance learning is carried out. desired. According to Purwanto and 
Juliana (2021), e-learning presents a completely new learning environment for students, so it requires different skills for successful learning, it can even improve critical thinking skills, research, and evaluation are increasingly important because students have different learning volumes.

\section{Method}

This type of research used explanatory with a quantitative approach using variance-based SEM analysis, this is because the dependent and independent variables in this study amounted to more than one so that they could use variance-based SEM to summarize the formulation of the analysis. The research population is graduate students with a sample of 150 doctoral students in Jakarta. The sample selection method is simple random sampling. The research method is a survey method with an associative approach. The data analysis technique is structural equation modeling (SEM) using SmartPLS 3.3.3 software. The hypothetical model built in this study is as follows:

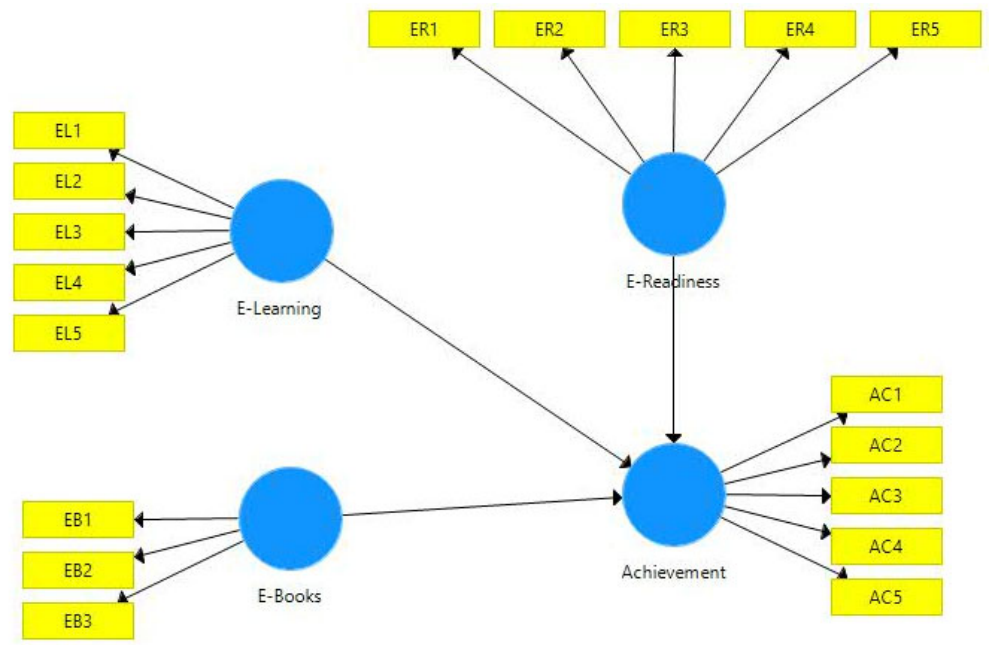

Fig. 1. Research model

Hypotheses 1: E-readiness has a positive effect on the achievement of graduate students.

Hypotheses 2: E-learning has a positive effect on the achievement of graduate students.

Hypotheses 3: E-book has a positive effect on the achievement of graduate students.

\section{Result and Discussion}

The tests carried out in the analysis of variance-based SEM has two stages, namely the outer model and the inner model test. The explanation of the test is as follows:

\section{Test Outer Model}

The convergent validity test on the outer model aims to determine whether the indicators with latent variables are valid, with a validity value above 0.70 (Purwanto et al., 2021). Fig. 2 shows that the validity value of each indicator is above 0.7 , so all research indicators are declared valid. In the outer model test in addition to convergent validity, there is also a validity reliability testing. The test aims to determine the reliability of the indicator in measuring the variable, while the variable is said to be valid if it has an AVE value above 0.5 and a Cronbach Alpha value above 0.7 (Purwanto et al., 2021), the following is a discriminant validity test in this study:

Table 1

Average Variance Extracted (AVE)

\begin{tabular}{cccc}
\hline Variables & Cronbach's Alpha & Composite Reliability & Average Variance Extracted (AVE) \\
\hline E-readiness & 0.748 & 0.855 & 0.663 \\
E-learning & 0.778 & 0.857 & 0.602 \\
E-books & 0.799 & 0.869 & 0.625 \\
Achievement & 0.789 & 0.865 & 0.746 \\
\hline
\end{tabular}




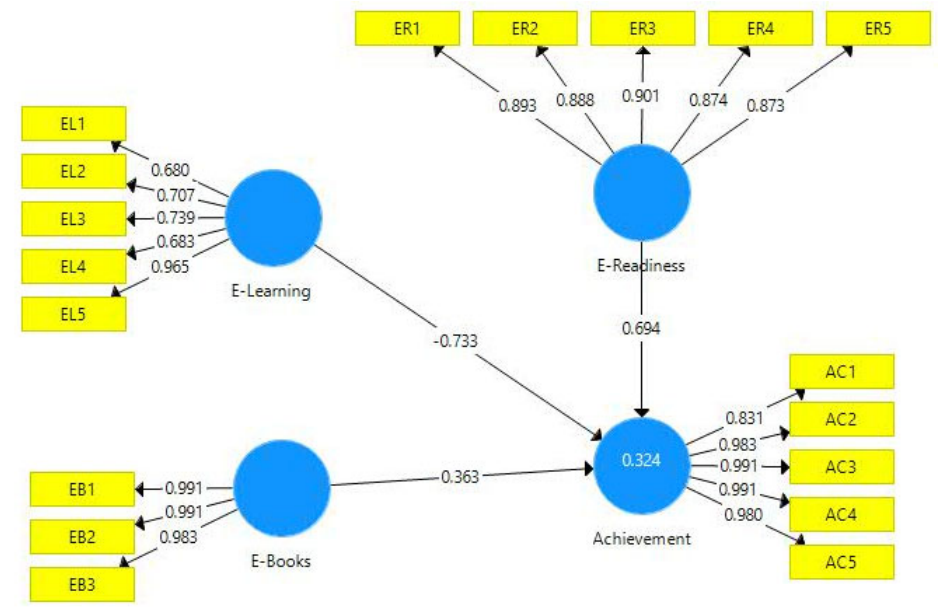

Fig. 2. Convergent Testing

Table 1 shows that all Cronbach alpha and average variance extracted values exceed the minimum limit so that all variables are declared valid.

\section{Inner model test}

The inner model test contains an explanation of the R-Square, while the R-square value in this study is as follows:

Table 2

R Square

\begin{tabular}{lll}
\hline Variable & R-Square & Adjusted R-Square \\
\hline Achievement & 0.324 & 0.325 \\
\hline
\end{tabular}

From the R square table, it can be concluded that $32.40 \%$ of achievement is influenced by E-readiness, E-learning and Ebooks, while the remaining $67.60 \%$ is influenced by other variables outside the study. In addition to reliability in the inner model test there is also a hypothesis test, while the hypothesis test in this study is as follows:

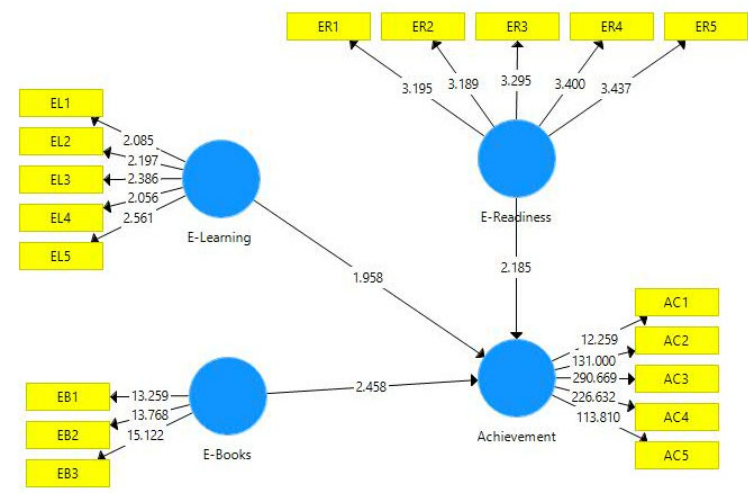

Fig. 3. Hypotheses Testing

Table 3

The summary of testing the hypotheses

\begin{tabular}{|c|c|c|c|}
\hline & Original Sample $(\mathrm{O})$ & T Statistics & P Values \\
\hline E-readiness $\rightarrow$ Achievement & 0.398 & 3.294 & 0.001 \\
\hline E-learning $\rightarrow$ Achievement & 0.722 & 8.634 & 0.000 \\
\hline E-books $\rightarrow$ Achievement & 0.483 & 4.035 & 0.000 \\
\hline
\end{tabular}

From the value of the hypothesis testing table, it is known that all hypotheses in the study are accepted because they have a p-value below 0.05 
According to Hair (2017) explains that the guidelines for assessing $\mathbf{f}^{2}$ are that values of 0.02 (= small), 0.15 (= moderate), and 0.35 (= large), respectively, represent small, medium, and low effects. large (Hair et al. 2020).

Table 4

$\mathrm{f}^{2}$ Effect Sizes Evaluation

\begin{tabular}{ccc}
\hline & Satisfaction & 0.31 \\
E-readiness & 0.29 \\
E-learning & 0.20 \\
E-books & 0.21 \\
\hline
\end{tabular}

For the E-readiness variable, the $\mathbf{f}^{2}$ value of 0.31 represents a big effect, for the E-learning variable, the $\mathbf{f}^{2}$ value of 0.29 represents a large effect, and for the E-books variable, the $\mathbf{f}^{2}$ value of 0.20 represents a large effect. for the Achievement variable, the $\mathbf{f}^{2}$ value of 0.21 represents a large effect.

\section{$Q^{2}$ Evaluation}

$\mathrm{Q}^{2}$ value is greater than 0 indicates that the model has predictive relevance for certain endogenous constructs. Conversely, values of 0 and below indicate a lack of predictive relevance (Hair et al., 2017).

Table 5

$Q^{2}$ Evaluation

\begin{tabular}{ccc}
\hline Construct & $\mathrm{Q}^{2}$ \\
\hline Achievement & 0.509 & 09 \\
\hline
\end{tabular}

The value of $\mathrm{Q}^{2}$ for the Achievement variable is $0.509>0.000$, meaning that this variable has predictive relevance.

\subsection{The first hypothesis: The effect of e-readiness on achievement}

Based on the SmartPLS analysis, it was found that the p value was $0.000<0.050$ and it was concluded that e-readiness had a positive and significant effect on Achievement. The higher the E-readiness, the better the Achievement. This result is in line with the results of research accomplished by Malshammari et al. (2019), Bubou et al. (2021), Bose et al. (2017) and Fernando et al. (2018) which stated that e-readiness had a positive and significant effect on achievement and also by Kolo and Zuva(2018), Kuruliszwili (2015), Kiilu et al. (2018) and Nisperos (2014) which stated that e-readiness had a positive and significant effect on achievement.

\subsection{The second hypothesis: The effect of e-learning on achievement}

Based on the SmartPLS analysis, it was found that the p value was $0.000<0.050$ and it was concluded that e-learning had a positive and significant effect on achievement. The higher the E-learning, the better the Achievement. This result is in line with the results of Yuliantoro et al. (2019), Purwanto and Juliana (2021), which stated that e-learning had a positive and significant effect on achievement. The results are also in agreement with Wijayaa et al. (2021), Haudi et al. (2021), which stated that E-learning had a positive and significant effect on achievement.

\subsection{The third hypothesis: The effect of e-book on achievement}

Based on the SmartPLS analysis, it was found that the p value was $0.000<0.050$ and it was concluded that E-books had a positive and significant effect on Achievement. The higher the E-books, the better the Achievement. This result is in line with the results of research by Haryudin and Imanullah (2021), Fernando (2018), Iffat et al. (2020) and Keshavarz and Noorafrooz (2020) which stated that E-books had a positive and significant effect on achievement and also by Haryudin and Imanullah (2021), Fernando (2018), Iffat et al. (2020) and Keshavarz and Noorafrooz (2020), which stated that E-books had a positive and significant effect on achievement.

According to Kolo and Zuva(2018), Kuruliszwili (2015), Kiilu et al. (2018) and Nisperos (2014), the learning used to implement the curriculum is in accordance with the development and needs of students to excel. Although the development of the e-learning method is not the only indicator of the small influence on the achievement of $\mathrm{PhD}$ students, of course there are other factors that contribute to the small influence of e-learning, including the readiness and ability of students to use information technology as a dominant support in developing e-learning. These results are in accordance with the results research conducted by Purwanto (2021) which states that the development of science and technology especially information technology helps for continues development of education. The use of the internet is not only for distance education, will but also it is used in conventional education. E-learning is a learning model made in digital format via electronic devices. 
The purpose of using e-learning in learning system is for expanding public access to education area, as well as in order to improve the quality of study. This finding is also supported by Purwanto (2020) who stated that there are positive effects of using internet in education, namely: a) Participants Learners can easily take the eye study anywhere in the world without institutional boundaries or national boundaries; b) Participants students can easily learn from teachers an expert in the field of interest; c) Lectures/study can be easily taken in various parts of the world without depending at the university/school where the student study. In addition, there is now a library for learning the effect of e-readiness, e-learning and e-book together on the achievement of graduate students. According to Wijayaa et al. (2021), Haudi et al. (2021), Yuliantoro et al. (2019), Purwanto and Juliana (2021) the availability of reading materials in the form of e-books that can be accessed by students in the lecture process is a part that does not have a dominant influence on graduate achievement. The availability of available software and hardware has become a part for students in the lecture process. Although there are other factors that influence achievement related to graduate competencies, this study only limits the study to the components or factors discussed above and does not examine other factors.

Haryudin and Imanullah (2021), Fernando (2018), Iffat et al. (2020), Keshavarz and Noorafrooz (2020) described the students who have high self-directedness. (1) High self-directedness is a person who has the initiative, independence, and perseverance to learn; (2) is a person who is responsible for his or her own learning and sees problems as challenges, not obstacles; (3) is a person who has self-discipline and has a high curiosity; (4) is a person who is confident and has a strong desire to learn or change; (5) is a person who is able to use learning abilities, organize time and determine the right steps for learning, and plan to complete tasks; (6) is a person who enjoys learning and tends to be goal-oriented. Students who are involved in the learning environment using e-learning are expected to have e-readiness. This is because e-readiness is an important key to e-learning success.

Therefore, it was concluded that there was an effect of using e-learning with google classroom and learning discipline on the learning motivation of brothers and sisters house students in Surabaya during the Covid-19 pandemic. This can be seen in student concentration where students understand the instructions given by the lecturer, concentrate on the teaching materials or materials provided by the lecturer, students record the material while learning is in progress, and students obey the existing rules from the lecturer when learning. Students' curiosity can be seen from students who will ask if there is material that cannot be understood, students ask the lecturer if they experience difficulties from the material that has been presented and are interested in the material or material presented by the lecturer. The spirit in which students will answer or do assignments that have been given from the lecturer, always enthusiastic in attending lectures and actively asking questions in lecture activities. Student readiness what is known from students is that they are always ready to answer or do assignments from the lecturer, prepare study equipment before class starts and students always reading reference books or literature books used by lecturers in lectures. Enthusiasm or unyielding encouragement from students who are always enthusiastic so that the tasks that have been done get the best possible grades, enthusiastic to do well on assignments, and enthusiastic students to complete assignments.

\section{Conclusion}

Based on statistical data management, the calculation of the effect of e-readiness on Graduate Achievement has shown that there is an effect of e-readiness on Graduate Achievement. Meanwhile, based on the calculation of the coefficient of determination, it has been concluded that the contribution of graduate achievement results was determined by e-readiness and was determined by other variables. The coefficient of the effect of e-learning on graduate achievement has shown that there is an effect of e-learning on graduate achievement. Meanwhile, based on the calculation of the coefficient of determination, it has been concluded that the contribution of graduate achievement results was determined by e-learning and was determined by other variables. The coefficient of the influence of e-books on graduate achievement has shown that there was an effect of ebooks on graduate achievement. Meanwhile, based on the calculation of the coefficient of determination, it was concluded that the contribution of graduate achievement results was determined by e-books and determined by other variables. Related to this, in this study there are several things that need to be considered, namely, Lecturers should fulfill and improve their competence by paying attention to lecture planning, communication with students, methods and strategies for lectures based on technology and information to create an innovative lecture process. Higher education institutions should improve lecture infrastructure, facilitate, and support lecturers and students to improve their competence. Students should follow the development of technology and information so that learning achievement can be optimal.

\section{References}

Alshammari, A. (2019). The Impact of E-Readiness on ELearning Success in Saudi Arabian Higher Education Institutions.

Bubou, G., \& Job, G. (2021). Benefits, Challenges and Prospects of Integrating E-Learning into Nigerian Tertiary Institutions: A mini review. International Journal of Education and Development using Information and Communication Technology, $17(3), 6-18$.

Bose, S. (2017). e-Readiness of State Open Universities towards Online Learning: A Study of BRAOU and UOU. Indian Journal of Open Learning, 26(3), 177-202.

Fernando, M. (2018). Pedagogical and e-learning techniques for quality improvement of ICT education. Advanced Learning and Teaching Environments: Innovation, Contents and Methods, 3-22. 
Haryudin, A., \& Imanullah, F. (2021). the Utilization of Kinemaster Applications in the Making of Multimedia Based Teaching Materials for English E-Learning in New Normal (Covid-19). PROJECT (Professional Journal of English Education), 4(2), 341-352.

Haudi, H., Rahadjengb, E. R., Santamoko, R., Putrac, R. S., Purwoko, D., Nurjannahe, D., ... \& Purwanto, A. (2021). The Role of e-Marketing and e-CRM on e-Loyalty of Indonesian Companies during COVID Pandemic and Digital Era. Uncertain Supply Chain Management, 10, 2022.

Iffat Rahmatullah, S., Sultana, S., \& Sultan, G. (2020). E-Teaching in Higher Education: an Innovative Pedagogy to Generate Digitally Competent Students at King Khalid University. E-Teaching in Higher Education: an Innovative Pedagogy to Generate Digitally Competent Students at King Khalid University.

Keshavarz, H., \& Noorafrooz, A. H. (2020). Dimensions of E-Readiness in University Libraries: Identification and Prioritization Using AHP Technique. Libri, 70(4), 319-333.

Kolo, I., \& Zuva, T. (2018). Comparison between the e-learning readiness of educators and learners in South African schools. In 2018 International Conference on Intelligent and Innovative Computing Applications (ICONIC) (pp. 1-6). IEEE.

Kuruliszwili, S. (2015). E-learning Readiness of Organization and Employees. International Journal of Electronics and Telecommunications, 61, 245-250.

Kiilu, R. M., Nyerere, J. K., \& Ogeta, N. (2018). Teacher-Trainee's Competency and Institutional Level of Preparedness for Adoption of E-Learning in Selected Teacher Training Colleges in Kenya. African Educational Research Journal, 6(2), 73-79.

Nisperos, L. S. (2014). Assessing the e-learning readiness of selected Sudanese Universities. Asian Journal of Management Sciences \& Education, 3(4), 45-59.

Purwanto, A., Asbari, M., \& Santoso, T. I. (2021). Education Management Research Data Analysis: Comparison of Results between Lisrel, Tetrad, GSCA, Amos, SmartPLS, WarpPLS, and SPSS For Small Samples. Nidhomul Haq: Jurnal Manajemen Pendidikan Islam, 6(2), 382-399.

Purwanto, A., Asbari, M., Santoso, T. I., Paramarta, V., \& Sunarsi, D. (2020). Social and Management Research Quantitative Analysis for Medium Sample: Comparing of Lisrel, Tetrad, GSCA, Amos, SmartPLS, WarpPLS, and SPSS. Jurnal Ilmiah Ilmu Administrasi Publik, 10(2), 518-532.

Purwanto, A., \& Juliana (2021). The effect of supplier performance and transformational supply chain leadership style onsupply chain performance in manufacturing companies. Uncertain Supply Chain Management, 10(2), 1-8

Timothy, M., Oladunjoye, J. A., \& Agu, E. O. (2016). Comparative study of e-learning experiences: A case study of Nigeria, South Africa and united states. International Journal of Grid and Distributed Computing, 9(10), 161-172.

Wijayaa, O., Sulistiyanib, S., Pudjowatic, J., Kurniasih, N., \& Purwanto, A. (2021). The role of social media marketing,entertainment, customization, trendiness, interaction and word-of-mouth on purchase intention: An empirical study from Indonesian smartphone consumers. International Journal of Data and Network Science, 5(3), 231-238.

Yuliantoro, N., Goeltom, V., Juliana, I. B., Pramono, R., \& Purwanto, A. (2019). Repurchase intention and word of mouthfactors in the millennial generation against various brands of Boba drinks during the Covid 19 pandemic. African Journal of Hospitality, Tourism and Leisure, 8(2), 1-11

Zdraveski, D., Sotiroski, K., Janeska, M., \& Manceski, G. (2021, July). E-Learning as a Contemporary Tool for Realization of Teaching Process-Statistical Analysis of Student's Perceptions. In International Scientific Conference Strategic Management and Decision Support Systems in Strategic Management (pp. 95-102).

Zubaedah, P. A. (2021). E-learning Implementation Assistance is Fun for Paud Teachers in Argasunya Village, Cirebon City. Devotion: Journal of Community Service, 2(2), 79-87.



(C) 2022 by the authors; licensee Growing Science, Canada. This is an open access article distributed under the terms and conditions of the Creative Commons Attribution (CC-BY). license (http://creativecommons.org/licenses/by/4.0/). 